\title{
Evaluation of the Cytotoxic Effects of Ultrasonic Extracts of Tribulus Terrestris L. on MCF-7 Cell Line by MTT Assay
}

Giray Bugra Akbaba ${ }^{1}$ Füreya Elif Ozturkkan ${ }^{2}$ Mustafa Sertcelik $^{2}$ (D)

${ }^{1}$ Kafkas University, Department of Bioengineering, Kars,!Turkey

${ }^{2}$ Kafkas University, Department of Chemical Engineering, Kars,!Turkey

A B S T R AC T
eople, especially those living in rural environments and those who have recently been
dissatisfied with traditional medicine, use medicinal plants for their therapeutic effects.
In this study, ethanol, ethyl acetate and methanol extracts of Tribulus terrestris L. plant,
which is used by local people as one of these medicinal plants in Kars province (Turkey),
were obtained by ultrasound assisted extraction method. The cytotoxic effects of the ob-
tained extracts on MCF-7 breast cancer cells in the concentration range of $10-1000$ ppm at
24 h of exposure were investigated by the MTT method, which is a colorimetric method.
T. terrestris L. ethanol extracts at 1000 ppm caused a moderate cytotoxic effect on MCF-7
breast cancer cells. It was determined that ethanolic extracts in the concentration range of
$10-500$ ppm and methanol and ethyl acetate extracts in the concentration of $10-1000$ ppm
caused cell proliferation.

\author{
Article History: \\ Received: 2021/07/16 \\ Accepted: $2021 / 11 / 20$ \\ Online: 2021/12/31
}

Correspondence to: Füreya ElifOzturkkan, Kafkas University, Department of Chemical Engineering, 36100, Kars, Turkey. E-Mail:fozturkkan36@gmail.com

Phone: +90 (535) 6522105

Fax: $+90(474) 2251160$

\section{Keywords:}

Tribulus Terrestris L.; MCF-7; Ultrasound assisted extraction; Cytotoxicity; MTT Assay

\section{INTRODUCTION}

T $\mathrm{t}$ is known that human beings used only natural 1 medicines until 1800 in the treatment of diseases. Compounds obtained through isolation from natural sources since the beginning of 1800 have been synthesized in the laboratory environment since 1830 [1]. In recent years, the belief that natural remedies are safer than synthetic drugs have led to an increase in people's use of natural products such as herbs, phytotherapeutics and phytopharmaceuticals Therefore, researchers conduct various studies on the biological significance of plant extracts [2, 3]. However, there is no regulatory system that determines the safety and required dose of natural products, or even commercially sells them. The most widely used of these natural products are herbs. Unfortunately, most of those who use these herbs therapeutically do not have adequate knowledge or training in the safe use of the products. For these reasons, many studies are required to standardize natural plant products and evaluate possible risks such as undesirable side effects, overdose and toxicity [4].

Tribulus terrestris L. is known in Turkey as "deve çökerten", "çoban çökerten" and "çarık dikeni”. These names were given to the plant because its fruit has horn-shaped spikes (Figure 1). The plant is of medicinal and pharmaceutical interest due to its steroidal saponin content $[5,6]$. Tribulus terrestris L., in addition to its hypolipidemic and hypoglycemic effects, is also used for the treatment of vitiligo, urological infections, prostatic hypertrophy, eye, abdomen and cardiovascular system diseases [6-8]. There are limited in vitro studies on the effect of T. terrestris L. extracts [7], which have low cytotoxicity on normal cells, on different cancer cells [7, 1012]. In this context, in this study, the cytotoxic effects of ethanol, ethyl acetate and methanol extracts of Tribulus terrestris L. on MCF-7 human breast cancer cell line for 24 hours were investigated by MTT Assay.

\section{MATERIAL AND METHODS}

\section{Collection of Chemicals and Plant Material}

Ethanol, ethyl acetate, methanol, DMSO, MTT, DMEM, Penicillin-Streptomycin, Fetal Bovine Serum (FBS), Phosphate Salt Buffer (PBS) and Trypsin EDTA (Sigma Aldrich, Germany) were commercially available. Tribulus terrestris L. aerial parts (leaf, fruit and stem) were collected from Kars, Turkey at the altitude of $1410 \mathrm{~m}$ at $40^{\circ} 29^{\prime} 46^{\prime \prime}$ North and $43^{\circ} 33^{\prime} 40^{\prime \prime}$ East coordinates. Map views related to these coordinates were obtained from Google Earth online and were gi- 


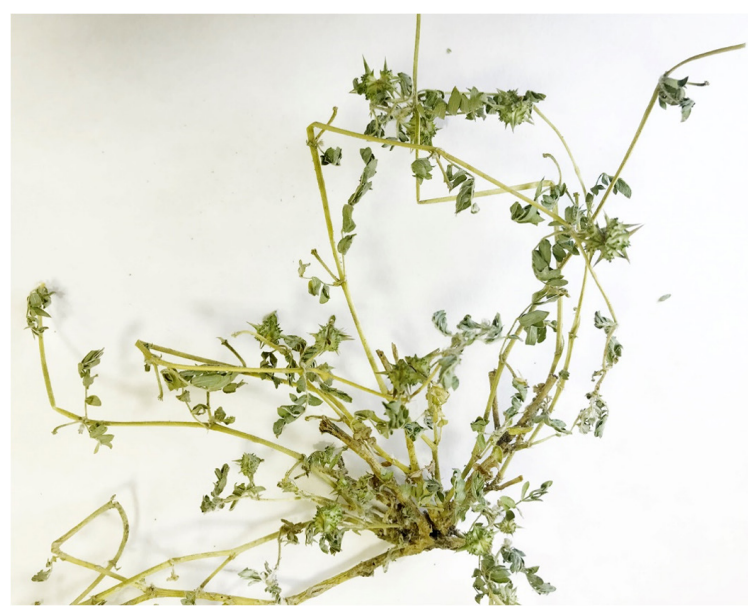

Figure 1. Tribulus terrestris L. plant

ven in Figure 2. The collected plant was described by Prof Dr. Fatma Güneş. The collected plant samples were dried in the dark and ground using a grinder.

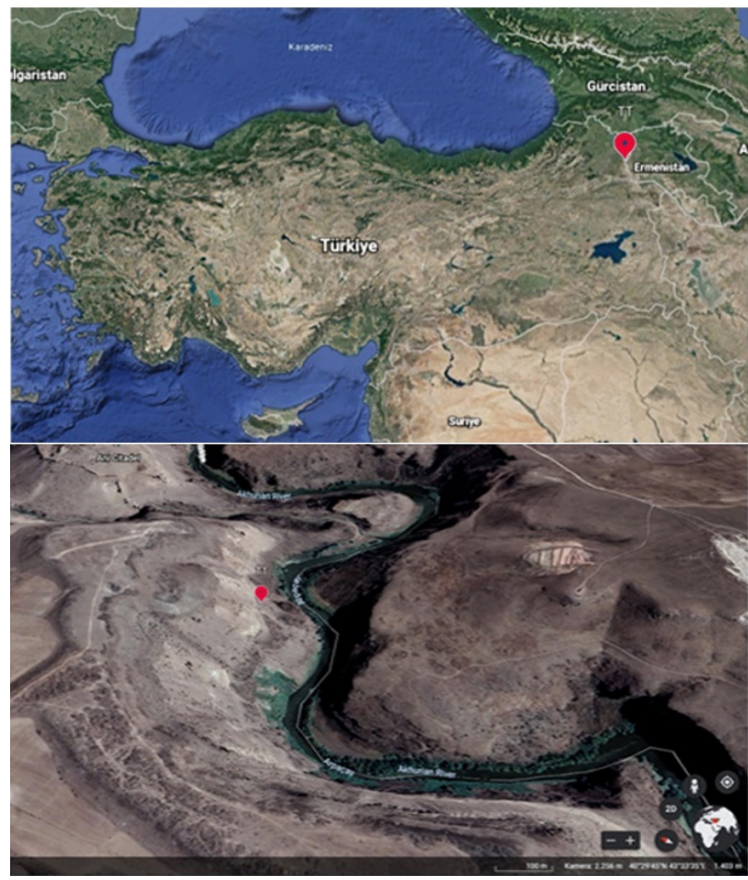

Figure 2. Map view of $40^{\circ} 29^{\prime} 46^{\prime \prime}$ North, $43^{\circ} 33^{\prime} 40^{\prime \prime}$ East coordinates where Tribulus terrestris L. samples were collected

\section{Instruments}

In this study, Bandelin Sonorex RK 106 at $35 \mathrm{kHz}$ frequency, Panasonic MCO-170AICUVH-PE CO2 Incubator, Hed Lab X BIO MSC CLASS II Biosafety cabinet, Thermo Fisher EVOS FL Inverted Microscope and BioTek Epoch UV-Vis Spectrophotometer were used.

\section{Plant Extraction}

For ultrasound assisted extraction, $10 \mathrm{~g}$ from the milled plant sample was weighed and placed in the round-bot- tomed flask, then added in a $30 \mathrm{~mL}$ the extraction solvent (ethanol, ethyl acetate and methanol). Extraction was continued $60 \mathrm{~min}$. Temperature was measured at $15 \mathrm{mi}-$ nutes intervals. The obtained extracts were filtered with blue band filter paper and the liquid part was dried in a rotary evaporator. For the MTT test, a stock solution of 1000 ppm was prepared and other solutions (500, 250, 100, $10 \mathrm{ppm}$ ) were prepared from this stock solution.

\section{MTT Assay}

$100 \mu \mathrm{L}(\sim 5000$ cells/well) of MCF-7 cell suspension prepared according to protocols [13] was placed in each well of 96-well plates and incubated for $24 \mathrm{~h}$. After incubation, $100 \mu \mathrm{L}$ aliquots from prepared solution (1000, 500, 250, 100 and $10 \mathrm{ppm})$ were added to the wells $(100 \mu \mathrm{L}$ of medi$\mathrm{um}+100 \mu \mathrm{L}$ of cell suspension was added to the control wells) and allowed to incubate again for $24 \mathrm{~h}$. Then, $10 \mu \mathrm{L}$ of MTT $(5 \mathrm{mg} / \mathrm{mL})$ solution prepared in PBS was added to each well and incubated for $4 \mathrm{~h}$. In order to dissolve the formed purple colored formazan crystals, $100 \mu \mathrm{L}$ of DMSO was added to all wells and incubated at $18 \mathrm{~h}$. After this period, absorbances were measured at a wavelength of $570 \mathrm{~nm}$ with a microplate spectrophotometer. Cell viability percentages were calculated with the following equation 1 . All experiments were performed in triplicate.

Cell Viability $(\%)=\frac{\text { Absorbance of test well }}{\text { Absorbance of control well }} \times 100$ (1)

\section{RESULTS AND DISCUSSION}

\section{Extraction}

Ultrasound assisted extraction is an important technology for green chemistry. The extraction process, which takes hours or days with traditional methods, can be completed in a short time thanks to ultrasound wave-assisted extraction. The most important advantages of this extraction method are short duration, high reproducibility, low solvent consumption and high purity of the final product $[14,15]$. The temperatures were recorded as 24 ${ }^{\circ} \mathrm{C}, 29^{\circ} \mathrm{C}, 34^{\circ} \mathrm{C}$ and $38^{\circ} \mathrm{C}$ (for ethanol); $25^{\circ} \mathrm{C}, 36^{\circ} \mathrm{C}, 42^{\circ} \mathrm{C}$ and $44{ }^{\circ} \mathrm{C}$ (for ethyl acetate) and $26^{\circ} \mathrm{C}, 32{ }^{\circ} \mathrm{C}, 38^{\circ} \mathrm{C}$ and $39{ }^{\circ} \mathrm{C}$ (for methanol) at $15,30,45$ and 60 minutes, respectively. The yields of extraction were found to be 45.25 $\%$ for ethanol, $52.39 \%$ for ethyl acetate and $62.64 \%$ for methanol.

\section{FT-IR Spectroscopy}

In many studies, it has been reported that ethanol, ethyl acetate and methanol extracts of the Tribulus terrestris 
L. plant are quite rich in terms of phenolic acids, flavonoids and saponins $[16,17]$. The biological activity of the plant is also attributed to these components. Dinchev et al. reported that there are saponins such as protodioscin, prototribestin, pseudoprotodioscin, dioscin, tribestin, tribulosin, rutin in the ethanolic extracts of the TT plant collected from Turkey [17]. Li et al also determined that the plant contains tigogenin, gitogenin, hecogenin and neohecogenin [18]. Reshma et al. attributed the antioxidant activity of ethyl acetate extracts of the plant to the total phenolic substance content and reported that it contains caffeic acid, chlorogenic and 4-hydroxybenzoic acid phenolic acids [19]. Phenolic compounds such as $\alpha$-Amyrin as the major component and 3,7,11,1-tetramethyl 2-hexadecen 1-01, n-hexadecanoic acid, hexadecanoicacid, ethyl ester, phytol, 1,2-octadecadienoic acid, 9,12,15-octadecanic acid, benzenedicarboxylic acid and diisooctyl ester as the minor component have been reported in the methanolic extracts of the plant [20]. In another study, it was determined that the methanolic extracts of the plant contain flavanoids such as naringin, rutin, hyperoside, quercetrin, quercetin, naringenin, hesperetin, campferol and apigenin, as well as phenolic acids such as pyrogallol, gallic acid, protocatechuic acid, catechin, catechol, chlorogenic acid, p-hydroxybenzoic acid, caffeic acid, vanillic acid, ferulic acid, salicylic acid, ellagic acid, coumaric acid and cinnamic acid [21]. These compounds generally have functional groups such as $\mathrm{O}-\mathrm{H}, \mathrm{C}-\mathrm{H}$ (aromatic), $\mathrm{C}-\mathrm{H}$ (aliphatic), $\mathrm{C}=\mathrm{O}, \mathrm{C}=\mathrm{C}, \mathrm{C}-\mathrm{H}$ bending and $\mathrm{C}-\mathrm{H}$ belonging to substituted benzene rings vibrations. When the FT-IR spectrums of the obtained extracts are examined, the vibrations of the $\mathrm{O}-\mathrm{H}$ groups are seen in the range of $3500-3200 \mathrm{~cm}^{-1}$. C-H stretching (aromatic), $\mathrm{C}-\mathrm{H}$ bending (aliphatic) and $\mathrm{C}-\mathrm{H}$ bending (substitue benzenes) vibrations are observed in the 3100$2900 \mathrm{~cm}^{-1}, 2900-2800 \mathrm{~cm}^{-1}$ and $850-700 \mathrm{~cm}^{-1}$ regions, respectively. The vibrations of the $\mathrm{C}=\mathrm{O}$ group are observed at $1750-1650 \mathrm{~cm}^{-1}$ (Figure 3-5).

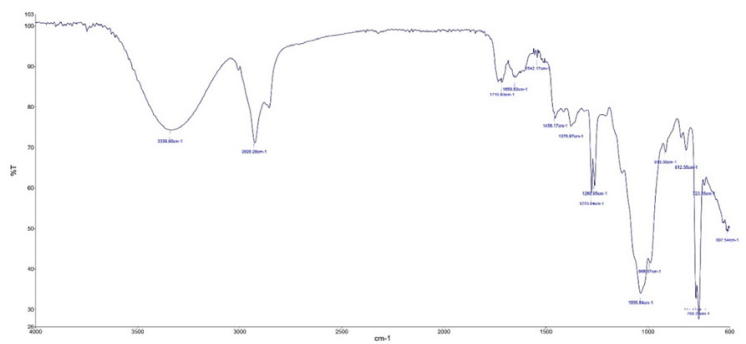

Figure 3. FT-IR spectra of ethanol extract of Tribulus Terrestis L.

\section{MTT Assay}

In this study, compared with the cell control group, it was determined that Tribulus terrestis L.'s methanol extracts caused proliferation of MCF-7 cells at all concentrations.

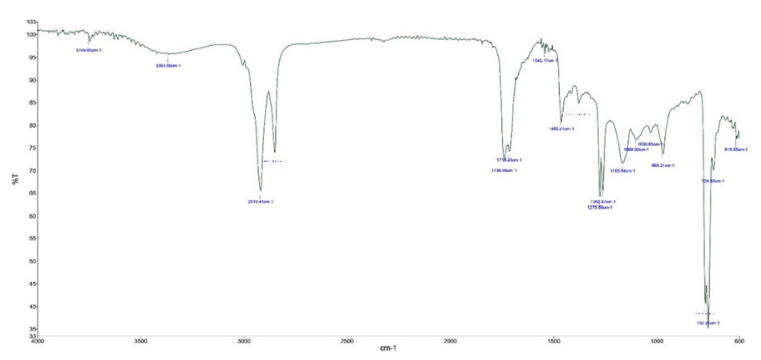

Figure 4. FT-IR spectra of ethyl acetate extract of Tribulus Terrestis L.

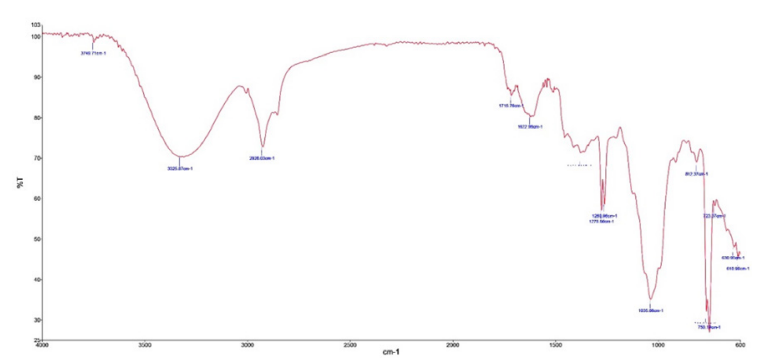

Figure 5. FT-IR spectra of methanol extract of Tribulus Terrestis L.

It was determined that cell proliferation increased with decreasing concentration. While $12 \%$ cell proliferation occurred at $1000 \mathrm{ppm}$ concentration, cell viability doubled $(210 \%)$ at $10 \mathrm{ppm}$ concentration. Methanol used as a solvent caused 5 \% cytotoxicity on MCF-7 cells (Figure 6).

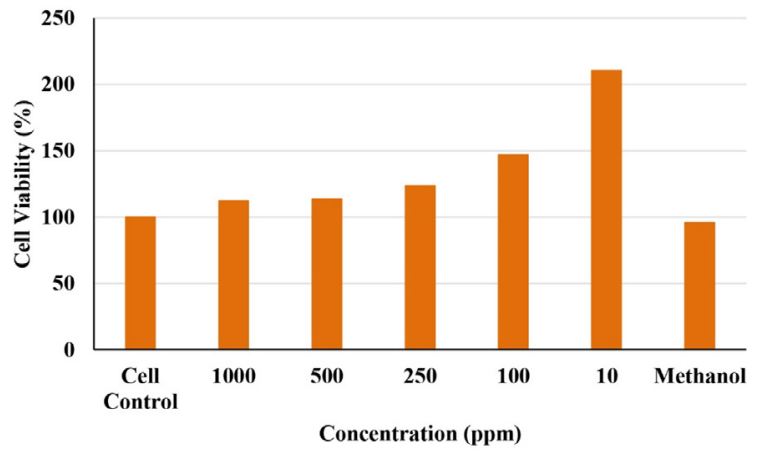

Figure 6. Effect of Tribulus terrestris L.'s methanol extract on MCF-7 cell line

The ethanolic extract of Tribulus terrestris L. at 1000 ppm concentration caused $19.9 \%$ cytotoxicity. Tribulus terrestis L. extracts at 500 ppm, 250 ppm, 100 ppm and 10 ppm concentrations caused proliferation in MCF-7 cells. While proliferation increased with decreasing concentration, more cell viability was found from the methanolic extracts of the plant. Ethanol used as a solvent also increased cell viability by $10 \%$ (Figure 7 ).

The effects of Tribulus terrestis ethyl acetate extracts on MCF-7 are similar to its methanol extracts. That is, the cell viability percentages are similar. $10 \%$ cell viability was found at $1000 \mathrm{ppm}$ concentration and $230 \%$ cell viability at $10 \mathrm{ppm}$ concentration. Ethyl acetate, which was used as a solvent, caused 9.3\% moderately cytotoxic [33] on MCF-7 cells (Figure 8). Comparison of effect of the all extracts on 
MCF-7 cell viability was given in Figure 9.

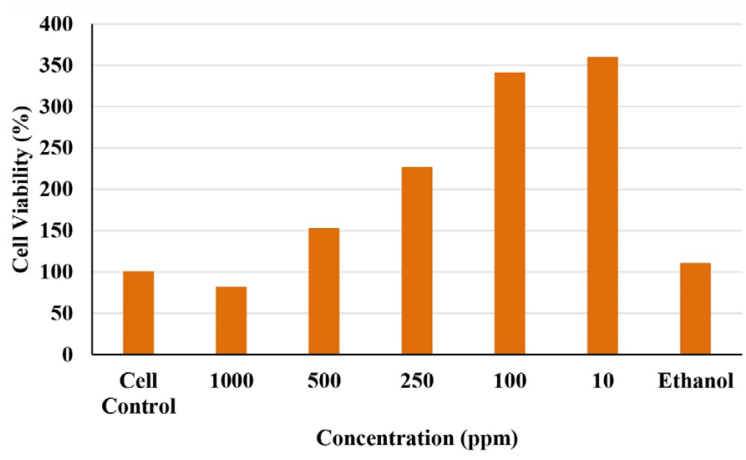

Figure 7. Effect of Tribulus terrestris L.'s ethanol extract on MCF-7 cell line

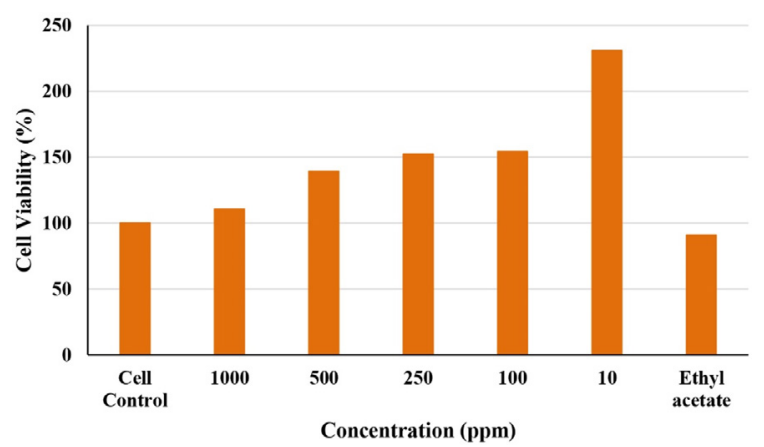

Figure 8. Effect of Tribulus terrestris L.'s ethyl acetate extract on MCF7 cell line

Ammar et al (2018) reported that methanol and petroleum ether extracts of $T$. terrestris $\mathrm{L}$. were cytotoxic to human hepatocellular carcinoma cells (HepG2) at $16.1 \mu \mathrm{g} \cdot \mathrm{mL}^{-1}$ and $21.5 \mu \mathrm{g} \cdot \mathrm{mL}^{-1}$ concentrations [21]. Angelova et al. (2013) examined the cytotoxic effects of T. terrestris extract on cell viability in human breast cancer (MCF-7) and normal (MCF10A) cell lines. It was determined that this plant extract inhibited the viability of breast cancer cells in a concentration-dependent manner (IC50 =15 mg/mL) [7]. Similarly, Neychev et al. (2007) found that the obtained saponins from $T$. terrestris exhibited low toxicity to normal human fibroblasts than some cancer cells [9]. Sun et al. reported that saponins isolated from the of T. terrestris L.'s ethanolic extract inhibited the proliferation of Bcap-37 breast cancer cell line and showed a cytotoxic effect on BEL-7402 cell line by causing apoptosis $[10,12]$. Wang et al. reported that steroidal saponins isolated from the T. Terrestris L.'s fruits exhibited antitumor property on NCI-H460, SF-268, MCF-7 and HepG2 tumor cells [22]. Abudayyak et al. examined the cytotoxicity of NRK-52E cells exposed to T. terrestris's methanol extracts for 24 hours by MTT assay. It was found that cell viability was $68.5 \%$ at $500 \mathrm{mg} / \mathrm{mL}$ concentration. The IC50 value was determined as $160 \mathrm{mg} / \mathrm{mL}$. It was determined that water and chloroform extracts of this plant did not show cytotoxic effects in the concentration range of 62.5$500 \mathrm{ppm}$ [23]. Chauhan et al. obtained the extracts of T. Terrestis fruits by mixing method in ethanol:water (1:1) solvent

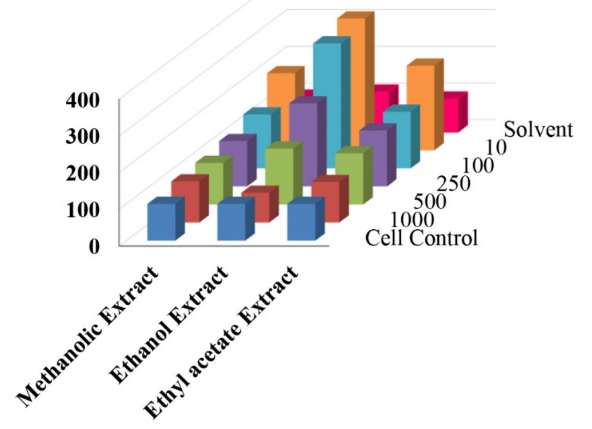

n Cell Control

$\because 1000$

$\square 500$

घ 250

घ100

$\square 10$

- Solvent

Figure 9. Comparison of effect of the all extracts on MCF-7 cell viability

mixture for 24 h. Researchers examined the effects of the extracts on HCT-15 cells in the concentration range of 10-70 ppm and found that the cells proliferated at 10 and $20 \mathrm{ppm}$. At $40-70 \mathrm{ppm}$, the cell viability was found as $25 \%$. They determined that cytotoxicity increased with increasing concentration [24]. In another study, the water:methanol (1:4) extracts of the fruits of the plant were obtained by the Soxhlet method. The effects of plant extracts on colon cancer cells (HT29) and prostate cancer cells (LNCaP-FGC-10) cells were investigated by MTT method. While colon cancer cell viability was $10 \%$ at 0.5 ppm, no cytotoxicity was observed on prostate cancer. At $12 \mathrm{ppm}$, the viability of prostate and cancer cells was reported as $10 \%$ and $30 \%$, respectively [25]. In addition, the aqueous extracts of this plant obtained by ultrasonic wave assisted extraction and these extract's cytotoxicity was investigated on Hepa 1c1c7 and Ovcar 3 cells. Apart from our study, this study is the only study in which ultrasonic wave assisted extraction method was used. Plant samples were purchased commercially and water was used as the extraction solvent. In these samples, only one caused severe cytotoxicity at 250 ppm and 500 ppm concentrations, while notable cytotoxicity was observed in the others [26]. Naz et al. evaluated the cytotoxicity of extracts of leaves and fruits of Tribulus Terrestis on brine shrimps. They used methanol as the extraction solvent. Leaf and fruit extracts at 1000 ppm concentrations exhibited mortality of $3.50 \%$ and $5.20 \%$, respectively. Mortality percentages at 10 ppm were reported as $1.55 \%$ and $2.65 \%$, respectively [27]. In a study by Menon et al., the effects of methanolic extracts of Tribulus Terrestis on DLA and EAC cells in the concentration range of 100-500 ppm were investigated by trypan blue exclusion method. Cell viability rates decreased below $50 \%$ at 380 and 420 ppm [28]. Gacche et al. obtained extracts of Tribulus Terrestis fruits with different solvents by Soxhlet extraction. Water extract, ethanol extract and chloroform extract caused cytotoxicity of $50 \%, 45 \%$ and $25 \%$, respectively, at 1000 ppm concentrations on HeLa cells [29]. The cell line we used in our study is MCF-7 breast cancer cell line. Patel et al. first extracted the plant with n-hexane and then re-extracted the defatted extracts with ethanol. It was determined that the seeds of the plant caused $47.02 \%$ cell vi- 
ability at 100 ppm concentration and $80.54 \%$ cell viability at $12.50 \mathrm{ppm}$ on MCF-7 cell line. It had been reported that the leaves of the plant cause $98.46 \%$ and $69.51 \%$ cell viability on MCF-7 cells at 100 ppm and 12.50 ppm concentrations, respectively [30]. The biological activity of a plant sample varies according to many conditions such as the solvent used in the isolation of its phenolic compounds, extraction technique, climate, coordinates, altitude, soil quality and fertilizer used [31, 32]. The results of previous studies are also very different from each other as they are heavily influenced by these factors.

\section{CONCLUSION}

In conclusion, according to the findings of previous studies, it was determined that saponins isolated from methanol and petroleum ether extracts and ethanolic extracts of $T$. terrestris L. cause cytotoxicity. In this study, the effects of the extracts of the aerial parts of the plant obtained by ultrasound assisted extraction using methanol, ethanol and ethyl acetate solvents on the viability of MCF-7 cells were investigated by MTT method. It was determined that only $1000 \mathrm{ppm}$ ethanol extract from the obtained extracts caused moderate cytotoxicity and cell viability was found approximately $80 \%$. In general, it was determined that $T$. terrestris L. ethanol, ethyl acetate methanol and extracts caused cell proliferation at all other concentrations. Also, breast cancer cells are strong cells compared to normal cells. The fact that the plant extract used in this study did not caused cytotoxicity is attributed to these reasons. Therefore, the use of Tribulus Terrestis L. plant collected for this study as an anticarcinogenic agent against breast cancer is not recommended. In addition, it is recommended that more studies be carried out for the use of plants for alternative treatment, especially in patients.

\section{ACKNOWLEDGEMENT}

The authors are thanked to Yıldırım Öztürkkan and Kenan Kara for their help in the collection of plant samples, and to Prof. Dr. Fatma Güneș for their support in plant identification, to Prof. Dr. Bingür Sönmez and Prof. Dr. Fikrettin Şahin for their support in the supply of cell lines, and to Prof. Dr. Hacali Necefoğlu, Dr. Cem Öziç, Dr. Yunus Ensari and Didem Yıldırım for their technical support.

\section{CONFLICT OF INTEREST}

The authors declare that they have no known competing financial interests or personal relationships that could have appeared to influence the work reported in this paper.

\section{AUTHOR CONTRIBUTION}

Giray Bugra Akbaba: Performing cytotoxicity experiments and Evaluation of Results; Füreya Elif Ozturkkan: Planning of the study, Performing all experiments Writing-Reviewing and Editing and Evaluation of Results; Mustafa Sertcelik: Performing extraction experiments

\section{References}

1. Alp M, Alp A.S. Medisinal Kimyaya Kısa Bir Giriş, 1st ed. Akademisyen Kitabevi, Ankara, 2019.

2. Özbek O, Berkel C, Gürdere MB, Budak Y, Özyigit C, Ceylan M, Yanar Y. The growth inhibitory potential of eudicot-based preparations against plant pathogenic fungi. Indian Phytopathology (2021) https://doi.org/10.1007/s42360-021-00366-8.

3. Özbek O, Budak Y, Berkel Ç, Özyiğit Ç, Yanar Y. The use of Marrubium vulgare L. plant extracts in the control of fungal plant pathogens. International Journal of Agriculture, Environment and Food Sciences 4(4) (2020) 476-482.

4. Ala AA, Olotu BB, Ohia CMD. Assessment of cytotoxicity of leaf extracts of Andrographis paniculata and Aspilia africana on murine cells in vitro. Archives of Basic and Applied Medicine 6 (2018) 61-65.

5. Evstatieva L, Tchorbanov B. Complex Investigations of Tribulus Terrestris L. for Sustainable use by Pharmaceutical Industry. Biotechnology \& Biotechnological Equipment 25 (2011) 2341-2347.

6. Hashim S, Bakht T, Marwat KB, Jan A. Medicinal Properties, Phytochemistry and Pharmacology of Tribulus Terrestris L. (Zygophyllaceae). Pakistan Journal of Botany 46 (2014) 399-404.

7. Angelova S, Gospodinova Z, Krasteva M, Antov G, Lozanov V, Markov T, Bozhanov S, Georgieva EI, Mitev V. Antitumor activity of Bulgarian herb Tribulus terrestris L. on human breast cancer cells. Journal of BioScience and Biotechnology 2 (2013) 25-32.

8. Kang LP, Wu KL, Yu HS, Pang X, Liu J, Han LF, Zhang J, Zhao Y, Xiong CQ, Song XB, Liu C, Cong YW, Ma BP. Steroidal saponins from Tribulus terrestris. Phytochemistry 107 (2014) 182-189.

9. Neychev VK, Nikolova E, Zhelev N, Mitev VI. Saponins from Tribulus terrestris L. Are Less Toxic for Normal Human Fibroblasts than for Many Cancer Lines: Influence on Apoptosis and Proliferation. Experimental Biology and Medicine 232 (2007) 126-33.

10. Sun B, Qu W, Bai Z. [The inhibitory effect of saponins from Tribulus terrestris on Bcap-37 breast cancer cell line in vitro]. Zhong Yao Cai $=$ Zhongyaocai $=$ Journal of Chinese Medicinal Materials 26 (2003) 104-106.

11. Bedir E, Khan IA. New Steroidal Glycosides from the Fruits of Tribulus terrestris. Journal of Natural Products 63 (2000) 16991701.

12. Sun B, Qu W, Zhang X, Yang H, Zhuang X, Zhang P. [Investigation on inhibitory and apoptosis-inducing effects of saponins from Tribulus terrestris on hepatoma cell line BEL-7402]. Zhongguo Zhong Yao Za Zhi = Zhongguo Zhongyao Zazhi = China Journal of Chinese Materia Medica 29 (2004) 681-684.

13. van Meerloo J, Kaspers GJL, Cloos J. Cell sensitivity assays: the MTT assay. Methods in Molecular Biology (Clifton, N.J.) 731 (2011) $237-245$. 
14. Al Jitan S, Alkhoori SA, Yousef L F. Phenolic Acids from Plants: Extraction and Application to Human Health. Studies in Natural Products Chemistry 58 (2018) 389-417.

15. Ötleş S, ed. Handbook of Food Analysis Instruments. CRC Press, Boca Raton, 2009.

16. Semerdjieva IB, Zheljazkov VD. Chemical Constituents, Biological Properties, and Uses of Tribulus terrestris: A Review. Natural Product Communications 14(8) (2019) 1-26.

17. Dinchev D, Janda B, Evstatieva L, Oleszek W, Aslani MR, Kostova I. Distribution of steroidal saponins in Tribulus terrestris from different geographical regions. Phytochemistry 69(1) (2008) 176186

18. Li T, Zhang Z, Zhang L, Huang X, Lin J, Chen G. An improved facile method for extraction and determination of steroidal saponins in Tribulus terrestris by focused microwave-assisted extraction coupled with GC-MS. Journal of Separation Science 32(23-24) (2009) 4167-4175.

19. Reshma PL, Lekshmi VS, Sankar V, Raghu KG. Tribulus terrestris (Linn.) Attenuates Cellular Alterations Induced by Ischemia in H9c2 Cells Via Antioxidant Potential. Phytotherapy Research 29(6) (2015) 933-943.

20. Abirami P, Rajendran A. GC-MS Analysis of Tribulus terrestris. 1 Asian Journal of Plant Science \& Research 1 (2011) 13-16.

21. Ammar NM, El-Din El-Hawary SS, Mohamed DA, Afifi MS, Ghanem DM, Awad G, Research Article Phytochemical and Biological Studies of Tribulus terrestris L. Growing in Egypt. International Journal of Pharmacology 14 (2) (2018) 248-259.

22. Wang J, Zu X, Jiang Y. Five furostanol saponins from fruits of Tribulus terrestris and their cytotoxic activities. Natural Product Research 23 (2009) 1436-1444.

23. Abudayyak M, Jannuzzi AT, Özhan G, Alpertunga B. Investigation on the toxic potential of Tribulus terrestris in vitro. Pharmaceutical Biology 53 (2015) 469-476.

24. Chauhan S, Sharma D, Goel HC. An in vitro evaluation of Tribulus terrestris L. fruit extract for exploring therapeutic potential against certain gut ailments. Indian Journal of Experimental Biology 56 (2018) 430-436.
25. Pourali M, Yaghoobi MM, Salehi Sormaghi MH. Cytotoxic, AntiProliferative and Apoptotic Effects of Tribulus terrestris L. Fruit Extract on Human Prostate Cancer Lncap and Colon Cancer HT29 Cell Lines. Jundishapur Journal of Natural Pharmaceutical Products 12 (2016) e33561.

26. Oliveira Filho CC, Kampke EH, Vargas TS, Salustriano NA, Scherer R, Fronza M, Campagnaro BP. In vitro cytotoxic activity of five commercial samples of Tribulus terrestris Linn in Espírito Santo (Brazil). Brazilian Journal of Pharmaceutical Sciences 53(4) (2018) e00262.

27. Naz R, Ayub H, Nawaz S, Islam ZU, Yasmin T, Bano A, Wakeel A, Zia S, Roberts TH. Antimicrobial activity, toxicity and anti-inflammatory potential of methanolic extracts of four ethnomedicinal plant species from Punjab, Pakistan. BMC Complementary and Alternative Medicine 17(1) (2017) 302.

28. Menon D, Dharmapal S, Raghavamenon A, Babu T. Cytotoxic and antitumor effects of Tribulus terrestris L fruit methanolic extract. Journal of Pharmacognosy and Phytochemistry 3(2) (2014) 1-4.

29. Gacche RN, Dhole NA. Profile of aldose reductase inhibition, anticataract and free radical scavenging activity of selected medicinal plants: An attempt to standardize the botanicals for amelioration of diabetes complications. Food and Chemical Toxicology 49(8) (2011) 1806-1813.

30. Patel A, Soni A, Siddiqi NJ, Sharma P. An insight into the anticancer mechanism of Tribulus terrestris extracts on human breast cancer cells. 3 Biotech 9(2) (2019) 58.

31. Fieldsend AF, Morison JIL. Climatic conditions during seed growth significantly influence oil content and quality in winter and spring evening primrose crops (Oenothera spp.). Industrial Crops and Products 12 (2000) 137-147.

32. Endes Z, Er F, Özcan MM, Juhaimi FA. Oil Content, Saturated and Unsaturated Fatty Acids of Some Linseed (Linum usitatissimum L.) Genotypes. Asian Journal of Chemistry 25 (2013) 9285-9287.

33. International Organization for Standardization. Biological evaluation of medical devices - ISO 10993, Part 5: Tests for in vitro cytotoxicity. Geneva, Switzerland; 1999. 